\title{
Criminal Law Review on Illegal Levies of the Parking Attendants
}

\author{
Ida Nursaadah ${ }^{1}$, Suparno ${ }^{2}$ \\ University of Borobudur ${ }^{1,2}$ \\ \{idaunbor@gmail.com¹, suparno@borobudur.ac.id²
}

\begin{abstract}
This paper is using qualitative approach by juridical normative method to review and expose the main problems related to criminal law for parking management who performed illegal levies. The search results related to the criminal law review of illegal levies, it is found that the implementation of efforts to combat illegal levies is carried out utilizing repressive means, namely through criminal law channels by carrying out arrest operations against perpetrators of illegal extortion and providing recommendations to law enforcers provide criminal sanctions against the perpetrators of criminal extortion.
\end{abstract}

Keywords: Criminal Code; Illegal Levies; Parking Attendant

\section{Introduction}

Illegal levies are increasingly prevalent among the public, due to the process of omission, both politically, legally, and socially. Politically, illegal levies are fertile because of the behavior of the city government and its officials. Even what a group of people does in collecting illegal retribution because it is legitimate by the behavior of certain individuals. Moreover, illegal levies collectors sometimes wear clothes that look as if they are official.

Therefore, the symptom of extortion is the process of community duplication of elite behavior. That is a group of people whose practices are carried out by the government elite. This becomes reasonable. This is because there are also many user charges on behalf of the city government but the accountability is not clear. Even though they used a piece of paper that was usually red or yellow as proof, people still questioned it. With that condition, the community can estimate. Is this fee money not included in the regional revenue report? For the city government's behavior at the root of the problem.

Although in the Criminal Code (KUHP), nothing is found regarding the crime of extortion or illegal extortion. However, it can be implicitly found in the formulation of corruption in Article 12 e of Law Number 31 of 1999 as amended by Law Number 20 of 2001 concerning corruption. Events in the field are far from the expectations of drivers, there are still many practices of levies. wild here and there. Either illegal levies are made outside the stipulated tariff or made without any applicable legal rules, the intention and purpose of which are not understood. Of course, this condition is a violation of the law, as well as detrimental and unsettling for inter-regional city transport drivers. Of course, it's not just happened without 
certain factors, which cause it to happen easily. Even the perpetrators in this case (illegal fees) are state officials who are supposed to dominate and protect the community.

The problem that arises is that parking attendants often charge fees for their services to motorists whom they like. The parking levy is a regional income in each region. For this reason, each parking fee is given a ticket, but what happens is that often parking attendants withdraw more parking fees than what is specified in the ticket. Those parking attendants still deposit the results of their parking to the local government but only what is stated on the ticket, the rest goes into private pockets.

Another case that occurs regarding parking services is that often motorists or vehicle users do not give them tickets and withdraw parking services at will. The responsibility of the parking manager, towards parking consumers, is to return the consumer's vehicle to its original state, or in other words if there is damage and even loss of the vehicle in the parking area is the responsibility of the parking manager. Vehicle users admit that they often lose their belongings or something the parking attendants do not want to take responsibility for. Parking attendants only guard the vehicle but if things happen that are not desirable, such as losing a helmet, jacket, or other, the parking attendant does not want to be responsible [1].

The Traffic Law Number 22 of 2009 has been enacted to replace Law Number 14 of 1992, with heavier sanctions for motorized vehicle users, both two-wheeled and four-wheeled / more who violate traffic regulations on roads. Regarding the existence of motorized vehicles and cars, the presence of parking attendants in each place is increasing. Parking attendants are divided into 2 (two), namely official parking attendants and illegal/unauthorized parking attendants. Therefore, the government is also expected to play an active role in providing official parking facilities so that there is no more illegal parking [2]. Based on this description, the paper will present a review of criminal law on illegal levies carried out by juridical normative parking attendants.

\section{Methodology}

This paper uses a qualitative approach with a normative juridical method [3] to be able to dissect and dissect the subject matter related to criminal law for parking managers who carry out illegal fees. Data collection was carried out in the literature, using documents and applicable laws, accompanied by prescriptive analysis [4] to be able to present data comprehensively.

\section{Result and Discussion}

Law is as a whole written and unwritten regulations that are usually compelling, for human behavior in state-society (as well as between countries), which leads to justice, for the realization of a peace order, to humanize humans in society [5]. Meanwhile, punishment is suffering that is deliberately imposed on a person who has committed an act that fulfills certain conditions. The definition of criminal law consists of norms containing requirements and prohibitions which (by the legislators) have been associated with a sanction in the form of punishment, namely specific suffering. Thus it can also be said that criminal law is a system of norms that determines which actions (things do something or do not do something where there is an obligation to do something) and in what circumstances can be imposed for actions [6]. 
Many experts argue that Criminal Law occupies a separate place in the systemic law, this is because criminal law does not place a separate norm, but strengthens norms in other areas of law by stipulating the threat of sanctions for violations of norms in other areas of law. Criminal law is a part of the overall law in force in a country, which establishes the rules and grounds for [5] :

a. Determine which actions are not allowed to be carried out and which are prohibited, along with threats or a sanction in the form of certain penalties for those who violate the prohibition.

b. As well as when and in what cases those who have violated the prohibition can be imposed or sentenced to a criminal penalty as has been threatened.

c. And determine how the imposition of a crime can be carried out if there are people who are suspected of having violated the prohibition.

Criminal law is a matter that regulates offenses and crimes against the public interest and the act is punishable by a criminal penalty which constitutes suffering. The definition above is following the principles of criminal law contained in Article 1 paragraph 1 of the Criminal Code where criminal law is based on written regulations (law in the broadest sense) is also referred to as the principle of legality.

The enactment of the legality principle provides a protective nature in the criminal law which protects the people against the unlimited exercise of power from the government. Characteristics of the law are accompanied by the threat of force and sanctions [7]. But the law is not forced to justify wrong issues or to force those who are not domiciled and do not bear. For the rules of social life to be obeyed and obeyed so that they become the rule of law, these social regulations must be equipped with an element of force.

Criminal action is a juridical meaning as it is to provide a definition or meaning of a legal term, so it is not an easy thing to provide a definition or understanding of the term criminal act. Discussion of criminal law is intended to understand the definition of the criminal as a sanction for the offense, whereas criminal prosecution concerning the fundamentals justifies the imposition of criminal and theories about the purpose of punishment. It should be stated here that, a criminal is a juridical term that has a special meaning as a translation of the Dutch language "straf" which can be interpreted as "punishment" [8].

Lawmakers have used the word "strafbaarfeit" to replace the term criminal act in the Criminal Code (KUHP) without explaining what is meant by the word strafbaarfeit so that various opinions arise in the doctrine of what exactly is meant. with the strafbaarfeit. Strafbaarfeit is the behavior of people (menselijke gedraging) formulated in the wet, which is against the law, which should be convicted (strafwaardig) and carried out by mistake. Concerning the issue of the definition of a criminal act, there are 3 (three) things that need to be considered [9] :

a. A criminal act is an act by a legal rule prohibited and punishable by punishment

b. Prohibition is aimed at an act, namely a situation or event which results from a person's behavior, while a criminal threat is directed at the person who caused the incident.

c. Between the prohibition and the threat of punishment, there is a close relationship because between the incident and the person who caused the incident. "An incident cannot be prohibited if the person who caused it is not a person, and a person cannot be punished if not because of the incident caused by it".

Regarding the definition of a criminal act, the term offense is used to translate strafbaarfeit and defines it as an act or act which is prohibited and is punishable by law. A general formulation regarding strafbaarfeit, namely a human behavior which at a certain time has 
been rejected in certain social life and is considered a behavior that must be eliminated by criminal law by using compelling means contained therein

Illegal levies (Pungli) are actions taken by a person or a civil servant or a state official by requesting payment of money that is not appropriate or there are no rules relating to the payment. This is usually equated with extortion, fraud, or corruption. According to Wikipedia, illegal levies are charges in place that are not supposed to be charged or levied. Often extortion is carried out by government officials or apparatus. Illegal levies are included in the category of occupational crimes, in which the concept of occupational crimes describes that an official for the benefit of himself or another person abuses his power to force someone to give something, to pay or receive a discounted payment, or to do something for himself.

In general, extortion is caused by uncertainty in services as a result of long and tiring service procedures so that people give up when dealing with corrupt public services. The articles related to illegal fees that have been mentioned above were then accommodated in drafting Law No.31 of 1999 concerning Corruption Crime which was renewed by Law No. 20 of 2001 concerning Eradication of Corruption Crimes, in the article of receiving gifts ( gratification), as follows: Article 12 letter e, Civil servants or state administrators whom to benefit themselves or others unlawfully, or by abusing their power force someone to give something, pay, or receive discounted payment, or to do something for himself; Article 12 letter f, Civil servants or state officials who, at the time of carrying out their duties, request, receive, or withhold payments to civil servants or other state administrators or the general treasury, as if they were civil servants or other state administrators or the general treasury. has a debt to him, even though it is known that it is not a debt; Article 12 letter g, a civil servant or state administrator who, at the time of carrying out his duties, asks for or receives a job, or delivers goods, is as if he owes him a debt, even though it is known that it is not a debt.

Several factors that caused someone to perform illegal extortion are [1] :

a. Misusing authority. The position or authority of a person can commit disciplinary violations by the perpetrator who carries out illegal fees.

b. Mental factors. A person's character or behavior in acting and exercising control over himself.

c. Economic factors. Income that can be said to be unable to meet the necessities of life which is not proportional to the task/position that a person is carrying out makes him motivated to commit extortion.

d. Cultural Factors and Organizational Culture. The culture that exists in an institution that runs continuously on illegal fees and bribery can be the cause of the occurrence of illegal levies to become commonplace.

e. Limited human resources.

f. Poor systems that control and supervise from superiors.

Parking is a phenomenon that affects the movement of vehicles that have such a high movement intensity, which will be hampered by vehicles parked on the shoulder of the road, causing congestion. In general, vehicles parked on the side of the road are around places or activity centers such as schools, offices, supermarkets, traditional markets, restaurants, and others. The effort that needs to be done to deal with the parking problem requires the provision of adequate parking space and the formation of an appropriate parking model for the available parking space, bearing in mind the need for parking lots and the necessary infrastructure must be following parking characteristics.

Parking should only be used to stop vehicles temporarily, not for long or days. A suitable and neat parking user will make it easier for parking attendants to park the vehicle. It can be underlined that the parking activity should not interfere with the movement of traffic and 
pedestrians, but in fact, the parking that has been taking place has often hampered traffic, resulting in congestion. This is due to improper use of parking lots [10]. Inaccuracy in the area and parking management causes irregularities in its regulatory side, resulting in the emergence of illegal levies committed by parking managers.

The first prevention of illegal levies is through penal measures through repressive measures. This repressive step itself is divided into two ways, namely through coercive repressive steps and persuasive repressive steps. These two steps are taken to control criminal acts of extortion committed by parking attendant managers. The implementation of efforts to combat illegal extortion is carried out by employing a repressive process, namely through criminal law channels by carrying out arrest operations against perpetrators of illegal extortion and providing recommendations to law enforcers to impose criminal sanctions on perpetrators of illegal extortion.

\section{Conclusion}

Illegal levies are authority abuse, the purpose of which is to facilitate the affairs or fulfill the interests of the payer. Extortion involves two parties (service users and unscrupulous officers), making direct contact to carry out secret or overt transactions. According to the $\mathrm{KPK}$, extortion includes gratuities that constitute an activity against the law, this case is regulated in Law No.20 of 2001 concerning Corruption Crimes. Criminal threats apply to Parking Attendants who make illegal fees, by collecting fees that are not following applicable regulations. One of the mechanisms for controlling is holding patrol activities. Considering that the human resources in the dissection of parking supervision and security that are owned are still limited, it is agreed that there will be a joint team from the police, and extortion team that is expected to improve the supervisory function in the field of parking activities carried out by parking attendants. Some of the activities for which the mechanism is determined are the process of determining fines/sanctions, and control outside the mechanism, such as the formation of control and supervision teams, controlling using tools.

\section{References}

[1] M. Sayadi, "Review of Illegal Levies Against City Transport Drivers in Wajo District," Universitas Negeri Makassar, 2013.

[2] Rahma, "Criminological Review of the Existence of Unauthorized Parking Attendants in Makassar City," Universitas Hasanuddin Makassar, 2015.

[3] M. Abdul Kadir, "Law And Legal Research.," Bandung PT. Citra Aditya Bakti., 2015.

[4] M. H. Dr. johnny ibrahim,SH., Normative Legal Research Theory \& Methodology. 2006.

[5] Muladi and B. N. Arief, Criminal Law Theories and Policies. Bandung: Alumni, 2005.

[6] T. Andrisman, Principles and Basic Rules of Indonesian Criminal Law. Bandar Lampung: Unila, 2009.

[7] M. Reksodiputro, Human Rights in the Criminal Justice System. Jakarta: Justice and Legal Services Center (Universitas Indonesia), 1999.

[8] i-lib Perpustakaan UGM, "Terrorism in the perspective of criminal law," Jurnal i-lib UGM. 2003.

[9] Moeljatno, Principles of Criminal Law. Jakarta: Bina Aksara, 1993. 
[10] S. Rahardjo, Law Enforcement Issues (A Sociological Review). Semarang: Genta Publishing, 2008. 